\title{
ANALISIS TINDAK TUTUR DIREKTIF ANAK USIA 4-5 TAHUN PADA BAHASA DI TK HARAPAN BARU MEDAN
}

\author{
Jans Linson Girsang ${ }^{1}$, Christin Agustina Purba*2 \\ Program Studi Pendidikan Bahasa dan Sastra Indonesia \\ Universitas Prima Indonesia \\ Janslinson29@gmail com.,chrisinpurba@unprimdn.ac.id
}

\begin{abstract}
ABSTRAK
Penilitian Mendeskripsikan bentuk tindak tutur di rektif yang digunakan anak 4-5 Tahun TAMAN Kanak kanak ( TK Harapan Baru Medan ) untuk mengetahui jenis tindak tutur direksi yang sering di gunakan anak usia 4-5 tahun Di Perguruan TK Harapan Baru 3 Medan. Penelitian ini menggunakan metode dengan desain penelitian Kualitatif dimana desaain penelitian ini menggunakan teknik pengmpulan data denga menggunakan metode observasi langsung dan wawancara di lapangan. Dengan populasi dalam penelitian ini adalah peser ta didik berusia 4-5 Tahun bentuk tindak tutur meminta secara langsung dan tidak langsung. Sedangkan bentuk mengizinkan secara lansung dan tidak langsung dan mengusulkan secara langsung Selain itu faktor - faktor intensitas munculnya ketiga tuturan tersebut lebih sering di bandingkan tindak tutur mengusulkan dan mengigizinkan dalam kehidupan. Hasil dari penelitian ini
\end{abstract}

Kata kunci : tindaktutur, bahasa anak 
English Language Teaching Prima Journal, Vol. 2, No. 2. 2021

e-ISSN: 2686-1526

\section{BAB I PENDAHULUAN}

Komunikasi dan tindak tutur merupakan dua hal yang tidak dapat dipisahkan karena tindak tutur selalu ada dalam pertuturan di tempat komunikasi terjadi. Hal ini juga menunjukkan bahwa tindak tutur memiliki peranan penting, sehingga keberadaannya selalu menarik untuk dikaji. Tindak tutur ini perlu dikaji untuk memberikan pemahaman bahwa fungsi bahasa bukan hanya sebagai media untuk berinteraksi di dalam masyarakat melainkan juga sebagai penyampaian pesan dari tuturan yang diucapkan. Tindak tutur merupakan analisis pragmatik, yaitu cabang ilmu bahasa yang mengkaji bahasa dari aspek pemakaian aktualnya (Hardiati, 2018: 124).

Bahasa adalah alat komunikasi antara anggota masyarakat berupa simbol bunyi yang dihasilkan oleh alat ucap manusia. Linguistik sebagai ilmu kajianbahasa memiliki berbagai cabang. Cabang-cabang itu di antaranya adalah fonologi, morfologi, sintaksis, semantik, dan pragmatik.

Tindak tutur ini juga bisa dituturkan oleh anak usia prasekolah. Menurut Luthfiyanti (2016: 129), anak pada usia TK atau prasekolah, bahasa yang mereka gunakan berbeda dengan bahasa yang digunakan anak usia SD, SMP, dan SMA/ SMK. Bahasa yang mereka tuturkan lebih sederhana dibandingkan dengan anak-anak yang usianya lebih tua. MenurutYusuf (2015: 162) anak usia prasekolah atau yang biasa dikenal anak usia taman kanak-kanak merupakan fase perkembangan individu sekitar 2-6 tahun. Pada masa ini, terjadi perkembangan yang sangat pesat pada anak. Perkembangan tersebut terjadi pada banyak aspek diantaranya perkembangan pada ranah bahasa.

Anak-anak merupakan bagian dari masyarakat tutur. Melalui bahasa mereka mampu berbicara sesuai dengan perkembangan usia dan lingkungannya. Tuturan anak akan bertambah apabila dia memasuki masa sekolah. Pada masa itu anak mulai berinteraksi dan berkomunikasi dengan teman sebaya, guru, orang tua, dan orang-orang di sekelilingnya. Menurut Alya (2009:765).

Tindak tutur adalah bagian dari pragmatik . Tindak tutur merupakan pengksud dari pembicara di ketahui pendengaran. Tindak tutur ( Spech atcs) adalah ujaran yang di buat sebagai bagian dari interaksi social. Menurut Leoni (dalam Sumarsono ,dan paina Pratama , 2010 :329330) tindak tutur merupakan merupakan bagian dari peristiwa tutur merupakan bagian dari peristiwa tutur, dan peristiwa tutur merupakan bagian dari situasi

Mengingat pentingnya bahasa maka seseorang harus mempelajari bahasa untuk Berkomunikasi dalam hal ini , pembelajaran bahasa sejak anak -anak, Blanger ( Alwi, 2003: 89) menyatakan bahwa perkembangan bahasa merupakan indicator seorang anak. oleh karena itu anak 
hendaknya di bimbing dan diarah untuk mempelajari bahasa pertamanya karena bahasa merupakan kemampuan yang harus di pelajari dan bukan kemampuan yang diwariskan secara biologis dari generasi berikutnya .Ariani ( 2005) dalam penelitiannya menemukan bahwa semua responden sudah. Berbagai bentuk tindak tutur antara lain:

1. BENTUK DIREKTIF dalam pertunjukan wayang lakon Dewaruci ini ditemukan dua puluh dua macam yaitu tindak tutur menyuruh,menasehati,meminta izin ,menguji ,meminta restu meningkatkan,memaksa ,merayu ,menantang ,menyarankan, memohon, memperingatkan,menganjurkan ,mengharap, mengajak menyela / interupsi, menegur memarahi ,menagih janji ,mempersilahkan ,menginterogasi ,melarang .

2. Fungsi dan makna tuturan tersebut dapat di ketahui setelah tuturan itu di gunakan dalam konteks pemakaian tuturan dalam peristiwa tutur di temukan dua puluh dua fungsi dan makna yang di gunakan dalam pertunjukan wayang lakon Dewaruci yaitu tindak tutur menasehati ,meminta izin ,menguji ,meminta restu , meningkatkan ,memaksa ,merayu ,menantang ,menyarankan ,memohon ,memperingatkan , menganjurkan , melarang. Setiap tindak tutur menghasilkan efek dari mitra tutur yang berbeda .

\section{Rumusan Masalah :}

1. Tindak tutur di realisasikan dalam modus oleh anak usia taman kanak -kanak

2. Jenis tindak tutur yang terjadi pada anak usia taman kanak -kanak dan

3. alas an tindak tutur direalisasikan dalam modus itu.

Sejalan dengan latar belakang masalah di atas, penelitian ini memiliki rumusan masalah yang harus dijawab yaitu tentang realisasi bentuk pemahaman anak usia pra sekolah terhadap pendidik, realisasi bentuk penerbitan TTD anak usia pra sekolah dan kaitan perkembangan pemahaman dan penerbitan tersebut dengan kesantunan.

Sejalan dengan rumusan masalah di atas, penelitian ini bertujuan untuk:

1. Mengidentifikasi realisasi bentuk pemahaman anak usia sekolah terhadap Anak didik ;

2. Mengidentifikasi realisasi bentuk-bentuk Pengajar yang diterbitkan oleh anak usia prasekolah; dan

3. Mengidentifikasi keterkaitan perkembangan pemahaman serta penerbitan anak usia prasekolah tersebut dengan kesantunan

\section{TUJUAN PENELITIAN}

Penelitian ini bertujuan untuk mengetahui :

1. Tindak tutur direalisasikan dalam modus oleh anak usia kanak -kanak 
English Language Teaching Prima Journal, Vol. 2, No. 2. 2021

e-ISSN: 2686-1526

2. Mengidentifikasi realisasi bentuk-bentuk pola bahasa anak yang diterbitkan oleh anak usia dini di sekolah

3. Mengidentifikasi keterkaitan perkembangan pemahaman serta guru yang mengajar anak usia dini

\section{Manfaat Penelitian}

Secara teori, hasil penelitian ini di harapkan berguna untuk menambah wawasan pengetahuan dalam ilmu bahasa, khususnya kajian pragmatik dan dapat memberikan masukan bagian penelitian yang lain apabila ingin meneliti pemerolehan bahasa anak.

Secara praktis di harapkan penelitian ini dapat memberikan sumbangan para pengetahuan bagi para pendidik atau pengasuh sekolah agar dalam membelajarkan peserta didiknya dapat melakukan strategi tindak tutur yang lebih mudah di cernah dan di pahami oleh peserta didik.

\section{RUANG LINGKUP PENELITIAN}

A. Penelitian dibatasi pada anak Taman Kanak-kanak TK HARAPAN BARU MEDAN Jalan Pintu lv Kelurahan Simalingkar Medan.

B. Fokus Penelitian hanya pada modus, jenis dan fungsi tindak tutur pada usia taman kanakkanak

C. Usia 4-5 TaD. Tidak meneliti bahasa apa yang mereka peroleh sebelumnya:

E. Terbatas pada Komunikasi lisan. 
English Language Teaching Prima Journal, Vol. 2, No. 2. 2021

e-ISSN: 2686-1526

\section{BAB II \\ KERANGKA TEORI}

\subsection{TEORI TINDAK TUTUR}

Teori tindak tutur sendiri berangkat dari ceramah filsuf berkebangsaan Inggris Jhon L. Austin pada tahun 1955 (1911-1960) yang kemudian diterbitkan pada tahun 1962 dengan judul How to Do Things With Words. Beliau menyatakan bahwa pada dasarnya pada saat seseorang mengatakan sesuatu, dia juga melakukan sesuatu. Tuturan merupakan produk penggunaan bahasa dalam bentuk lisan maupun tulisan melalui struktur linguistik yang berhubungan atau tidak pada kalimat. Adapun tindakan adalah sesuatu yang dilakukan oleh seseorang secara aktif. Searle (1974:16) berpendapat bahwa

more precisely, the production or issuance of asentence token under certain conditions is aspeech act, and speech act (of certain kinds to be explained later) are the basic or minimal units of linguistik communication.

dalam artian tindak tutur, dan tindak tutur (dengan jenis tertentu untuk dijelaskan kemudian) adalah dasar atau unit minimal linguistik komunikasi'. Dalam linguistik komunikasi, bahasa bukan sekadar simbol, kata, atau kalimat, melainkan sebuah produk dari simbol, kata, atau kalimat dalam kondisi atau

konteks tertentu dan terwujud sebagai tindak tutur. tindak tutur, tindak tutur dapat dikatakan sebagai suatu yang sebenarnya kita lakukan ketika kita berbicara,

Menurut Chaer dan Leoni (2004:53), tindak tutur dibagi dalam tiga jenis, yaitu tindak tutur lokusi, ilokusi, dan perlokusi. Tindak tutur direktif, tindak tutur direktif adalah jenis tindak tutur yang dipakai oleh penutur untuk menyuruh orang lain melakukan sesuatu (Yule, 2006:93). jenis tindak tutur direktif, Gunarwan (1994:48), menyatakan bahwa yang tergolong ke dalam tindak tutur direktif adalah menyuruh, memohon, menuntut, menyarankan, menantang peristiwa tutur, Chaer (2004:47) mengemukakan, bahwa yang dimaksud dengan peristiwa tutur adalah terjadinya atau berlansungnya interaksi linguistik dalam satu bentuk ujaran atau lebih yang melibatkan dua pihak, yaitu penutur dan lawan tutur dengan satu pokok tuturan.

\subsection{Bahasa}

Bahasa merupakan alat komunikasi yang di pergunakan oleh manusia untuk berintraksi sosial. Setia manusia menggunakan bahasa untuk berhubungan dengan sesamenya. Mengingat pentingnya bahasa maka seseorang harus mempelajari bahasa untuk berkomunikasi dalam hal ini, pembelajaran bahasa perlu dilakukan sejak Anak - Anak. Berkaitan dengan pelunya pembelajaran bahasa sejak Anak - Anak ( Alwi n,b2003: 89). Menyatakan bahwa perkembangan bahasa merupakan indicator seorang anak .oleh karena itu ,anak hendaknya di bombing dan di 
arahkan untuk mempelajari bahasa pertamanya karena bahasa merupakan kemampuan yang harus di pelajari dan bukan kamampuan yang di wariskan secara biologis dari generasi berikutnya . Atiani (2005)

\section{A. Teori Modus}

Menurut Kamus Besar Bahasa Indonesia (2006:75) modus bentuk verba yang mengungkapkan suasana kejiwaan sehubungan dengan perbuatan menurut tafsiran pembicara tentang apa yang diungkapkannya. Dalam kamus Linguistik, modus adalah kategori gramatikal dalam bentuk verba yang mengungkapkan suasana psikologis perbuatan menurut tafsiran pembicara,atau sikap pembicara tentang apa yang diucapkan ( Kridalaksana,2008: 156).

Secara linguistic ,modus dapat didefinisikan sejumlah konsep sebagai berikut.

A. Mood adalah kategori gramatikal dalam bentuk verba :

B. Mood mengungkapkan suasana Psikologis perbuatan:

\section{B . Teori Tindak Tutur}

Teori tindak tutur sendiri berangkat dari Ceramah Filsuf Austin Pada tahun 1995 (1911-1960) yang kemudian diterbitkan pada tahun 1962menyatakan bahwa pada dasarnya pada saat seseorang mengatakan sesuatu, dia juga melakukan sesuatu.

Tuturan merupakan produk penggunaan bahasa dalam bentuk lisan maupun tulisan melalui struktur linguistic yang berhubungan atau tidak pada kalimat . Adapun tindakan adalah sesuatu yang dilakukan oleh seseorang secara aktif. Searle (1974:16)

\section{Jenis Tindak Tutur}

1. Austin ( 1968 : 107) membedakan tiga jenis tindakan yang berkaitan dengan ujaran.Ketiganya adalah 1). Tidak lokusi yakni tuturan yang sesuatu :2) tindak ilokusi ,yakni tuturan yang menyatakan sekaligus melakukan suatu tindakan dan 3) tindak perlokusi adalah adalah tuturan yang mempunyai daya pengaruh terhadap petutur untuk melakukan sesuatu.Searle (1969)

2. Menguraikan tindak ilokusiner yang merupakan bagian sentral dalam kajian tindak tutur di bagi menjadi lima kelompok : representative , direktif, komisi,ekspresif, dan deklarasi. 


\section{Pemeroleh Bahasa dan pemerolehan pragmatic.}

3. Pemerolehan bahasa merupakan suatu proses yang digunakan oleh kanak-kanak untuk menyesuaikan serangkaian hipotesis yang makin bertambah rumit atau teori-teori yang masih

4. Terpendam, yang mungkin terjadi dengan ucapan $\mathrm{d}$

5. engan ucapan orang tua sampai dia memilih ukuran penilaian tatabahasa yang terbaik dan sederhana dari bahasanya ( Simanjuntak, 1987:157).

6. Seperti disarankan oleh nino dan snow , paling tidak kita perlu mempelajari:

1. Pemerolehan niat Kreatif (Communiative intents) dan pengembangan ungkapan bahasanys:

2. Pengembangan kemampuan bercakap -cakap dengan segala aturannya:

3. Pengembangan piranti untuk membentk wawacana yang kohesif ( Dardjowidjojo 2000: 43-44)

Early childhood atau kadang dinamakan usia sekolah ( play group) adalah periode dari akhir masa bayi sampai umur lima atau enam tahun. Selama periode ini , anak menjadi makin mandiri, siap untuk bersekolah (seperti mulai belajar untuk mengikuti perintah dan mengidentifikasi huruf) dan banyak menghabiskan waktu bersama teman.

Selepas taman kanak-kanak biasanya dianggap sebagai batas berakhirnya periode ini. Anak-anak dengan mobilitas yang mulai meningkatkan memiliki akses ke jaringan social yang lebih luas dan perkembangan kognitif menjadi semakin dalam. 
English Language Teaching Prima Journal, Vol. 2, No. 2. 2021

e-ISSN: 2686-1526

\section{BAB III}

\section{METODE PENELITIAN}

Penelitian ini merupakan penelitian pragmatik karena penelitian ini memfokuskan pada bahasa yang digunakan untuk berkomunikasi dalam situasi tertentu. Dalam penelitian pragmatik makna suatu bahasa diberi definisi dalam hubungannya dengan penutur atau pemakai bahasa. Leech (1972) dalam Nadar (2009:2) mengungkapkan bahwa kajian pragmatik menekankan pada dua tipe makna yaitu intended meaning 'makna yang diinginkan oleh penutur' dan interpreted meaning 'makna yang diinterpretasikan oleh mitra tutur' yang ada dalam pikiran mitra dalam mengolah dan membuat interpretasi yang diperolehnya saat memperoleh informasi ketika sedang berkomunikasi.

Pada penelitian pragmatik tidak lepas dari istilah konteks. Mey (1998 dalam Nadar 2009:3 - 4 ) mendefinisikan konteks sebagai situasi lingkungan dalam arti luas yang memungkinkan peserta tutur dapat berinteraksi dan yang membuat ujaran mereka dapat dipahami. Sedangkan Levinson (1983:9) mendefinisikan pragmatik sebagai kajian hubungan antara bahasa dan konteks yang tergramatikalisasi atau terkodifikasi dalam struktur bahasa. Penelitian ini memfokuskan pada bentuk tindak tutur direktif yang diterbitkan oleh anak usia

\section{Penyediaan Data}

Tahapan penyediaan data adalah tahap mengumpulkan data. Data yang dimaksud adalah fenomena lingual khusus yang berkaitan langsung dengan masalah yang dimaksud. Pada bagian penyediaan data ini dibahas mengenai data.

Tipe Memerintah 1) Kategori Memerintahyang muncul pada kelompok usia 4 - 5 tahun antara lain: a) Memerintah Sub memerintah pada kelompok usia ini terlihat pada ujaran berikut: Konteks : Putri diperintah oleh Tracy untuk memindahkan barang yang tidak pada tempatnya di tempat lain. /Oleh : "Taruh di sini aja ya." (Tracy) Mitra Tutur : "Ya.” (Putri)

b) Menyuruh menyuruh terlihat pada contoh berikut: Konteks : Saat masih di kelas, Bu Nela mendatangi tiap kelas untuk mengingatkan anak siapa saja yang mau menabung. Kemudian Rafi menyuruh Fari untuk pergi ke Bu Lia /Oleh : " Kamu ke bu Nella, bilang ini buku Rafi, ya!." (Rafi) Mitra Tutur : "Ya." (Feri).

c) Meminjam Contoh meminjam yang muncul pada kelompok usia ini adalah: Konteks : Putri menginginkan kertas yang lebih besar untuk melukis /Oleh : Boleh pakai kertas yang ini nggak Bu? (Putri) Mitra Tutur : 'Boleh (Bu Sri) d) Menyilahkan menyilahkan dapat dilihat . 


\section{BAB IV}

\section{HASIL PENELITIAN}

\begin{tabular}{|c|c|c|c|}
\hline No & PENELITIAN & JUDUL PENELITIAN & HASIL PENELITIAN \\
\hline 1. & $\begin{array}{l}\text { Norttyani } \\
(2014)\end{array}$ & $\begin{array}{l}\text { Tindak tutur direktif pada perkembangan } \\
\text { Anak Play group di kota Solo. }\end{array}$ & $\begin{array}{l}\text { Hasil penelitian bahwa } \\
\text { tindak tuturdirektif berupa } \\
\text { kata angan (jangan) dan } \\
\text { ekspresif berupa kata jelek }\end{array}$ \\
\hline 2. & $\begin{array}{l}\text { Hardiati } \\
(2018)\end{array}$ & Tindak Tutur Bahasa Anak & $\begin{array}{l}\text { Hasil Penelitian Makna dari } \\
\text { Tuturan yang di ucapkan } \\
\text { seseorang.Ketika seseorang } \\
\text { mengatakan, tengorokan } \\
\text { saya kering . maka tuturan } \\
\text { tersebut bisa memiliki } \\
\text { banyak Arti tergantung dari } \\
\text { Situasi bahasa. }\end{array}$ \\
\hline 3. & $\begin{array}{l}\text { Dardjowijoyo } \\
(2006)\end{array}$ & Pemakaian Bahasa (language usage) & $\begin{array}{l}\text { Hasil Penelitian } \\
\text { Menggunakan bahasa Tidak } \\
\text { baku sehari hari . }\end{array}$ \\
\hline
\end{tabular}

\section{HASIL DAN PEMBAHASAN}

Ada beberapa kelompok Anak perempuan usia (4-5 Tahun ) Sebanyak 6 orang anak .Dalam penelitian ini dapat kita lihat cara gaya percakapan Anak-anak TK Harapan Baru Medan tidak jauh berbeda dengan cara kerja orang dewasa pada umumnya.

Contoh 1: Kamu ,nggak bawa bonto

2: Ada Snack saya , tapi saya tidak lapar'”

\section{Memberikan Giliran Bicara}

(A) Dalam teknik alih tutur ini ,Anak memberikan giliran berbicara dan memberikan kesempatan kepada anak-anak yang lain

(B). Anak memberikan kesempatan kepada teman tindak tuturnya. 
English Language Teaching Prima Journal, Vol. 2, No. 2. 2021

e-ISSN: 2686-1526

Contoh : 1. Saya Tidak membawa Snack

2. Saya bawa, ini sambil menunjukan snacknya

\section{MENGAMBIL ALIH GILIRAN BERBICARA}

Teknik ini dilakukan apabila anak memperoleh giliran dengan memberikan temanya berbicara . kadang anak merebut kesempatan berbicara di saat teman temanya juga berbicara ,karena ingin membela diri masing-masing,menonjolkan diri dan menarik perhatian. Kemudian anak juga mengganti objek percakapan yang menarik.

CONTOH : 1. Wahh Tinggal dua nih, boleh kaaah saya memintanya satu intan? ( meminta dengan sopan keppada Temanya ) Satu untuk Kevin satu untuk Sinta dan satu untuk kamu (sambil menunjukan tempat bekalnya kuenya yang tidak berisi lagi. 
English Language Teaching Prima Journal, Vol. 2, No. 2. 2021

e-ISSN: 2686-1526

\section{BAB V}

\section{KESIMPULAN dan SARAN}

\section{KESIMPULAN}

Berdasarkan hasil dan pembahasan terhadap data penelitian maka sebagai jawaban atas rumusan masalah penelitian dapat disumpulkan : bahwa tindak tutur berdasarkan maksud ujar di reali Alisasikan dalam modus kalimat.

Tindak tutur direktif menyuruh strategi bertutur yang paling dominan guru gunakan adalah strategi bertutur terus terang tanpa basa-basi, dan kesantunan anak -anak berbahasa menggunakan maksim kesepakatan.

Seperti guru bertutur kurang sopan dengan menggunakan bahasa yang kurang mendidik seperti penggunaan bahasa daerah yang agak kasar dituturkan kepada siswa.

\section{SARAN}

Kajian ini kiranya dapat ditindak lanjuti terhadap penelitian tindak tutur pada anak usia taman bermain ( Play group ) maupun anak dibawah usia tiga tahun (balita). Peran serta orang tua dan tenaga pendidikan terhadap keterampilan berbicara usia dini, khususnya dalamfungsi tindak tuturnya . Keterampilan berbicara yang optimal dapat meningkatkan melalui keterampilan berbahasa sebagai pembentuk kepribadian, sikap,

Pengetahuan dan kemampuan komunikasi anak sehungga menjadi individu yang mandiri. 
English Language Teaching Prima Journal, Vol. 2, No. 2. 2021

e-ISSN: 2686-1526

\section{DAFTAR PUSTAKA}

Hardiati,wiwin.2018. Tindak tutur Sarkastik di Media Sosial . Jurnal Bahasa, Sastra ,dan Pembelajarannya.8(1) : 123-131.

Luthfiyanti ,Lita .2016.Jenis dan fungsi Tindak Tutur Guru dan siswa dalam proses BelajarMengajar di TK IT Ukhuwah Banjarmasin. Jurnal Bahasa, Sastra, dan Pembelajarannya.6(1) : $128-143$.

Miles,Mattew. B dan Huberman, A. Michael.2014. Analisis Data Kualitatif (terjemahan oleh Tjetjep Rohendi Rohidi). Jakarta: Ul-Press.

Novita, Haeriyah. 2018. Pemerolehan Kalimat Bahasa Indonesia Anak Usia Lima Tahun. Jurnal BAhasa, SAstra, dan Pembelajarannya. 8 (2) : 245-255.

Otto , Beverly. 2015.Perkembangan Bahasa Pada Anak Usia Dini .TErjemahan oleh Tim Penerjemahan Prenadamedia Group 2015. Jakarta : Prenadamedia Group.

Rafiek, M \& Noortyani, Rusma2014. Pemeroleh an Fonologi Anak di Tiga Paud Kecamatan Banjarmasin Utara. Jurnal Bahasa,Sastra, dan Pembelajarannya, 4(2) : 163-183. 